PART TWO

Social and Economic Rights That Are Fundamental to Equality 



\title{
The Right to Education
}

\author{
A Foundation for Equal Opportunities
}

\section{A LONG HISTORY OF EXCLUSION}

History is littered with countries actively denying the chance for an education. In the United States, colonies and then states enacted laws that prohibited educating African American slaves in the eighteenth and nineteenth centuries. ${ }^{1}$ South Carolina, for example, passed a law in 1740 imposing a $£ 100$ fine-equivalent to over $\$ 21,192$ in $2019^{2}$ - on anyone who dared to "teach or cause any slave or slaves to be taught to write," ${ }^{3}$ while Virginia's 1819 Revised Code proclaimed that providing schools for slaves would be considered "unlawful assembly," punishable by 20 lashes. ${ }^{4}$ The result was widespread exclusion, particularly across the American South: according to the 1850 Census, of the 58,558 African Americans in Texas, just 397 were free-of whom 20 were in school..$^{5}$

In South Africa, the Dutch settlers established schools for African slaves in the seventeenth century, but they focused solely on religious instruction, and largely served as tools for social control rather than empowerment. ${ }^{6}$ In the mid-nineteenth century, the governor of the Cape of South Africa described the purpose of educating black South Africans as "peaceful subjugation," while curricula designed for black students focused on the skills required to perform manual labor.7

In both countries, segregation of public schools came later, after courts and legislatures had begun ruling against complete exclusion. ${ }^{8}$ In 1889 , South Africa's 
superintendent general for education argued in Parliament for "a differentiated education thereby ensuring that the Whites maintained their supremacy, while the mass of Africans were confined to a humbler position."9 In the post-Civil War U.S., many states' laws and constitutions mandated public school segregation; in Alabama, the 1901 constitution's requirement that "[s] eparate schools shall be provided for white and colored children, and no child of either race shall be permitted to attend a school of the other race" remains, despite ballot initiatives in 2004 and 2012 proposing its removal. ${ }^{\circ}$

Beyond limiting access to education on the basis of race, governments have systematically excluded immigrants, girls, and children with disabilities. In California, which saw an influx of labor migrants from China and Mexico in the late nineteenth century, employers complained that "the schools teach Mexicans to look upon farm labor as menial," ${ }^{11}$ while the state superintendent argued against funding schools for Chinese students given their supposed lack of interest in learning. ${ }^{12}$

In Afghanistan, girls have faced a series of evolving barriers to education for centuries. In 1919, Habibullah Khan, the country's ruler since 1901, was assassinated after attempting to open a school for girls. ${ }^{13}$ In 1923, Habibullah's son Amanullah drafted Afghanistan's first constitution, and continued his father's fight for girls' education. However, after Amanullah raised the minimum age of marriage to 18 and banned polygamy, a council of tribal leaders and elected officials rebuked his leadership and ordered the closure of the girls' schools in Kabul and rural areas. ${ }^{14}$ In the decades since, girls have faced persistent obstacles to accessing education, most recently resulting from the Taliban's closure of schools, particularly those for girls, across the country. Today, according to UNICEF, $60 \%$ of Afghan girls aged 7-17 are out of school. ${ }^{15}$

\section{EDUCATION AND THE FIGHT FOR EQUAL RIGHTS}

South Africa, the United States, Afghanistan, and other governments denied certain populations access to education because they recognized its fundamental role in empowering people to fight for equality. Education (both informal and formal) provides individuals and communities with knowledge of their civil, political, social, and economic rights, how these compare to the rights of others, avenues for seeking change, and tools for recourse upon experiencing discrimination and rights violations. Therefore, in a book fundamentally about equal rights, we believe it is essential to examine whether everyone has the right to an affordable, accessible, quality public education.

The right to education is also firmly grounded in international human rights agreements including the Universal Declaration of Human Rights, the International Covenant on Economic, Social and Cultural Rights (ICESCR), and the U.N. Convention on the Rights of the Child (CRC). What difference have education rights made, and what more must be done to ensure all children have the opportunity to learn? 


\section{India: Marching for a Constitutional Right to Education}

On June 19, 2001, after a 115-day journey, a group of 150 activists, teachers, and citizens reached the Indian capital of Delhi, where temperatures neared 100 degrees Fahrenheit. The group had already traveled over 15,00o kilometers across 20 states, rallying thousands of supporters along the way. ${ }^{16}$ Their mission? The enactment of a fundamental right to education.

The Shiksha Yatra, or March for Education, was the culmination of over a decade of activism and legal action aimed at strengthening the constitution's protections of education. India's independence constitution, enacted in 1949 following the end of British colonial rule, was among the first to include a comprehensive list of social, economic, and cultural rights, in addition to the civil and political rights that have been common in constitutions for centuries. Yet most of the social and economic rights, including the right to education, were enacted in a separate section of the constitution reserved for "directive principles," whereas the civil and political rights were categorized as fundamental rights. As the constitution explicitly noted, this distinction meant that although it was the "duty of the state to apply" the directive principles, they "shall not be enforced in any court." ${ }^{17}$

In the decades following the constitution's adoption, India's economy grew substantially. Yet the pace of progress in education gradually slowed. By 1990, just seven girls were in primary school for every ten boys, and 90 million children aged 6-14 were out of school in $1991{ }^{18}$ Literacy rates had improved markedly since the 1950 s but remained low when viewed in a global context, with only $64 \%$ of men and $39 \%$ of women able to read and write in $1991 .{ }^{19}$ Advocates and civil society groups began identifying the education provision's nonbinding nature as part of the problem, arguing that over four decades since the constitution's birth, it was time for a stronger legal commitment to free education to accelerate progress toward its full realization.

Two early 199os Supreme Court cases, Mohini Jain v. State of Karnataka ${ }^{20}$ and Unni Krishnan J.P. v. State of Andhra Pradesh, ${ }^{21}$ became the catalysts for change. While both cases actually dealt with fees for higher education, the Court took the opportunity to examine the constitutional "right to education" more generally. Article 45 stated: "The State shall endeavour to provide, within a period of ten years from the commencement of this Constitution, for free and compulsory education for all children until they complete the age of fourteen years." Noting that the education provision was the only directive principle that included a time frame for its realization, the Court observed that the drafters clearly understood it to be particularly consequential, and urged that after 44 years, the constitutional aspiration to provide universal education should become a reality. The Court found further support for this interpretation in the ICESCR. Finally, the Court reasoned that Article 21 of the constitution, which guarantees the "right to life" and "right to liberty," is enforceable and justiciable, and basic education provides the foundation for these rights-making education justiciable by implication. 
While celebrated by activists, the Court's rulings on free education also stirred controversy about the scope of judicial review; critics questioned whether the Court had overstepped its bounds. ${ }^{22}$ To ensure the right to education had a stronger legal basis, the National Alliance on the Fundamental Right to Education, a network of nearly 2,400 civil society groups from around the country, began organizing around a constitutional amendment that would clearly establish education as a fundamental right. ${ }^{23}$

In 1997, a bill was introduced to amend the constitution to create an enforceable right to free education for all children ages 6-14; after a change of government, it was reintroduced in 2001. The civil society movement embarked on the Shiksha Yatra that same year, spearheaded by the South Asian Coalition on Child Servitude, a national child rights organization. And in December 2002, after passing both houses of Parliament and attaining presidential assent, the Eighty-sixth Amendment became law. ${ }^{24}$

India's "Right to Education" movement strikingly illustrates a common issue regarding constitutional protections for social and economic rights. While some constitutions guarantee these rights through authoritative language and make clear they can be claimed in court, others describe them in aspirational or conditional terms - for example, by urging states to "endeavor to protect" the right to education or by guaranteeing the right "subject to available resources." Compared to leaving the right to education unaddressed, these aspirational approaches signal that ensuring all children can attend school is a priority. Citizens and civil society can leverage aspirational rights to advocate for more inclusive and progressive educational policies. However, the conditional language implies limits on the extent to which the right can be enforced.

Although the resulting amendment still has its critics-including those who feel it did not go far enough, as it guarantees free education only for ages 6-14-India's right to education movement provides a prime example of how civil society can employ the constitution to meaningfully advance equal rights. Through key court decisions and the engagement of thousands of citizens seeking change, an aspirational constitutional provision transformed into an enforceable right, building a strong legal foundation for millions of children to access basic education. Since 2000, India has reduced the number of out-of-school children by over $90 \%$ and closed the gender gap in both primary and lower secondary school enrollment. ${ }^{25}$

\section{Colombia: Fulfilling the Right to Free Education for Internally Displaced Children}

Enshrining educational rights in constitutions, rather than legislation alone, matters-especially against the backdrop of social or political instability. In 2002, the same year India enacted its constitutional amendment, halfway around the world, a record number of Colombians were displaced by civil war, which had embroiled 
their country since the 196os. A ten-year-old at the time, José vividly remembers the day his family was forced to flee their home in Tolima, Colombia: "They said that if we didn't leave, they would kill us. They gave us half an hour to leave." ${ }^{26}$ On average, every ten minutes, a family was forced to gather their most essential possessions and flee, often under threats of violence or accusations of "collaboration" with the government. José and 13 of his relatives left immediately, migrating over 100 miles to Bogotá.

For children like José, forced displacement was a destabilizing, traumatic experience, with both immediate and long-term impacts. As in many conflict situations, children have faced among the most devastating and enduring consequences of the violence in Colombia. Despite parents' best efforts to reestablish a sense of normalcy for their kids, financial barriers often put school-central to children's healthy development, opportunities, and daily life-out of reach. The devastation disproportionately affected families that were already marginalized. For some families in desperate economic circumstances, it can feel like a necessary choice to have children work rather than finish their education. In Colombia in the early 20oos, compounding this issue was the government's imposition of tuition-even for public primary school.

Numerous personal accounts revealed the burden of tuition on families trying to rebuild their lives. On top of tuition fees, children like Eduardo, an eighth grader, found themselves facing additional $\$ 4$ monthly charges just for water, not to mention the costs of uniforms, books, and backpacks. ${ }^{27}$

In the context of Colombia's economy at the time, these expenses were often debilitating. According to the Colombian Commission of Jurists, as of 2003, the average annual cost of sending a student to school in Bogotá equaled around three months' work at the minimum wage. ${ }^{28}$ For many displaced families in Colombia, the cost burden was untenable. In 2002, fewer than $9 \%$ of the displaced children in 21 "receiving communities" were attending school, compared to $93 \%$ of all children living there. ${ }^{29}$ In a study of why displaced children were leaving school, the Colombian ombudsman's office found that education costs outweighed almost every other factor. ${ }^{30}$ By the early 200os, it was becoming undeniably clear that the displacement crisis would put its youngest victims at a lifelong disadvantage.

However, the Colombian Coalition for the Right to Education, in partnership with DeJusticia, a Colombian NGO focused on social and economic rights, saw an opportunity to shift the tide for José and his peers-and it started with the constitution. The option to charge primary school tuition had been instituted by a 1994 law that departed from Colombia's legal tradition, since the 1930s, of guaranteeing free education. ${ }^{31}$ Challenging the law, DeJusticia pointed to Article 67 of Colombia's 1991 constitution, which guaranteed free education. But Article 67 qualified this guarantee with the phrase "without prejudice to charges for the cost of academic rights for those who can afford them," which some argued allowed for charging tuition or fees if affordable. The DeJusticia lawyers argued that Colombia's 
constitutional history made clear that fees were never permissible at the primary level. Moreover, Colombia's regional and international commitments bound the country to ensure that primary education was compulsory and tuition-free.

The Constitutional Court agreed. International treaties ratified by Colombia, including the ICESCR, unequivocally protected the right to free primary education; under Article 93 of the constitution, these treaties were legally binding and enforceable. Further, the Court affirmed that given how the right to education had developed in Colombia, the 1991 constitution's cost-related provision clearly "was never meant to apply to tuition fees for primary education and therefore not to modify the standard of free education as set forth in the previous Constitution." ${ }_{32}$ Accordingly, Judge Luis Ernesto Vargas Silva found that charging tuition for public primary school was unconstitutional.

The Colombian court's decision was a major step forward. Overnight, primary school became free by law, benefiting millions of children nationwide, including the vast numbers affected by displacement. ${ }^{33}$ The decision also brought Colombia in line with every other Latin American country, which had already guaranteed free primary education. ${ }^{34}$

Furthermore, the case underscored the power of establishing the right to free education through constitutions rather than statutes or policies. Because Colombia constitutionally guaranteed the right to free education for those who could not afford fees, it provided DeJusticia with the strongest basis for challenging legislation curtailing that right.

\section{The Power of Constitutional Education Rights- and Questions for Their Design}

Together, these cases from India and Colombia illustrate that constitutional rights to education have powerfully aided efforts to strengthen children's educational opportunities, with particular benefits for marginalized students. They also demonstrate the feasibility of guaranteeing the right to free education even in lowerand middle-income settings.

However, the differences between these two countries' approaches to the right to education raise key questions, relevant across contexts. For example, is it best to guarantee a broad right to education, or are constitutions most effective when they specifically guarantee primary or secondary education? At each level, what should the guarantees include? In practice, can these provisions advance both access to education and its quality? And finally, how should a constitution negotiate the relationship between these protections and a country's level of economic development?

After diving deeper into the evidence on why education matters for equalityand what barriers remain for achieving universal education-this chapter examines these more pragmatic questions, drawing on further examples from around the world to understand the potential for impact of constitutional education rights. 


\section{THE TRANSFORMATIVE POTENTIAL OF EDUCATION}

Leaders around the world have highlighted the transformative power of education, from South African president Nelson Mandela, who in 2003 declared education "the most powerful weapon we can use to change the world,"35 to Malala Yousafzai, who in advocating for girls' education urged the U.N. General Assembly: "[L] et us pick up our books and our pens, they are the most powerful weapons. One child, one teacher, one book and one pen can change the world. Education is the only solution." ${ }^{36}$ As both speakers' words make clear, education is important not just for each child, but for our collective well-being and broader struggles for equality. Innumerable studies back these calls up.

\section{Individual Earnings and Employment}

Across high- and low-income countries alike, evidence shows that increased educational attainment leads to higher-paying jobs, lower unemployment rates, and even higher agricultural productivity. ${ }^{37}$

In the United States, adults with a college degree earn about 50\% more than those who have completed only high school, and are less than one-third as likely to be unemployed..$^{8}$ Similarly, across OECD countries, employment rates for 25 to 34 -year-olds with a tertiary education range from 8 to 43 percentage points higher than for those who did not finish high school. ${ }^{39}$ Education economically benefits residents of low- and middle-income countries (LMICs) as well as highincome countries, and rural areas as well as urban. In a study of 73 countries, the average rate of return, as measured by earnings per additional year of schooling, is $9.7 \%$, ranging from $7.4 \%$ in high-income countries to $10.7 \%$ in middle-income countries and $10.9 \%$ in low-income countries, with the highest rates of return estimated in Latin America and the Caribbean (12\%) and sub-Saharan Africa $(11.7 \%) .{ }^{40}$ In Uganda, farmers who have completed four years of primary school are estimated to increase crop production by $7 \%$, while seven years of primary school are associated with a $13 \%$ increase; given that the majority of Ugandan families live in rural areas and practice subsistence farming, these findings have tremendous practical import. ${ }^{41}$

While the trends are consistent, increased education does not always lead to markedly improved employment prospects. In some settings where the supply of high-skill jobs is limited, a university degree might not be the primary pathway to economic security. Still, despite varying impacts across settings and from person to person, the evidence is strong that, on the whole, higher educational attainment supports higher earnings and employment rates.

\section{Health}

Increased educational attainment is also associated with better health outcomes. ${ }^{42}$ For example, a study of 22 European countries found that adults who 
had completed upper secondary or higher education were commonly 2-3 times more likely to report being in good health than individuals with less education. ${ }^{43}$ A study of 80 LMICs found that increases in women's educational attainment accounted for $14 \%$ of the reductions in under-five mortality, $30 \%$ of the reductions in adult female mortality, and $31 \%$ of the reductions in adult male mortality from 1970 to $2010 .{ }^{44}$ The study further estimated that educational gains saved 7.3 million lives across LMICs from 2010 to $2015 .{ }^{45}$ Likewise, a study spanning 95 LMICs found that a one-year increase in girls' education was associated with a $3.6 \%$ decrease in under-five mortality from 1970 to $2004 .{ }^{46}$ These benefits are likely explained partly by education's impact on socioeconomic status, but literacy and formal schooling may also independently affect healthcare practices and behaviors, with benefits for entire families. ${ }^{47}$

\section{Gender Equality}

While education benefits all children, expanding girls' access to education can be especially powerful, both because girls have historically received less formal schooling than boys and because of the multigenerational benefits. Staying in school is associated with lower rates of early marriage, fertility, and maternal mortality, in addition to improved long-term economic opportunities and autonomy. ${ }^{48}$ For each additional year a girl stays in school, her wages rise $10-20 \%{ }^{49}$ With increased income, women can exercise greater autonomy and assume a greater role in household decision-making, which often leads to higher spending on children's health and education..$^{50}$

Children whose mothers have had access to education often have lower mortality and malnutrition rates, higher immunization rates, and overall better health..$^{51}$ In a study of families in Malawi, Tanzania, and Zimbabwe, when mothers had a least a secondary school education, their children's odds of stunting (impaired growth) decreased by $44 \%, 69 \%$, and $49 \%$, respectively, compared to mothers without any formal education..$^{52}$ Likewise, a 56-country study concluded that increased maternal education reduced the odds of stunting in both "low-burden" and "highburden" countries. ${ }^{53}$ Husbands' health benefits as well. In Bangladesh, men with more educated wives face lower mortality risks regardless of their own education or occupation. ${ }^{54}$

\section{Benefits for National Economies}

Finally, when more children get an education, countries' economies do better. A study of the OECD found that greater educational attainment was responsible for around half the economic growth across 30 countries between 1960 and 2008. ${ }^{55}$ Meanwhile, discrimination and unequal opportunities in education have the opposite effect; according to the International Labour Organization and the Asian Development Bank, gender disparities in access to education in the Asia and Pacific region diminish overall GDP by up to $\$ 30$ billion yearly. ${ }^{56}$ Similarly, 
across many African countries, girls' high dropout rates dramatically reduce economic growth. ${ }^{57}$ According to estimates by Plan International, the collective costs of failing to close the gender gap in education across 65 LMICs amount to $\$ 92$ billion annually..$^{8}$

\section{PERSISTING BARRIERS}

\section{Poverty}

Although the barriers to equal access to education are wide-ranging, poverty is a common thread. Child labor, driven largely by families' underlying economic circumstances, jeopardizes millions of children's opportunities to stay in school. And both paid child labor and unpaid family labor at high hours impede children's ability to learn even if they can attend school. In addition, the direct costs of attending school, including tuition and fees for books, uniforms, or other materials, put education out of reach for many. These fees also disproportionately affect girls, since investing in boys' education is often viewed as a higher priority due to cultural norms and labor market discrimination that may reduce women's earning potential. Disadvantage due to poverty and gender compound one another. According to UNESCO, "girls from the poorest families in sub-Saharan Africa will only achieve [universal lower secondary school completion] in 2111, 64 years later than the boys from the richest families." ${ }^{59}$

\section{Quality and Value}

Second, even where children are in school, ensuring that they receive quality education, particularly in lower-resource areas, remains a key challenge. In at least 26 countries (including 23 in sub-Saharan Africa), the average student-teacher ratio exceeds 40:1 in primary schools. ${ }^{60}$ And in some countries, teachers are only required to have a few more years of education than their students. ${ }^{61}$ UNESCO reports that just one-third of primary-age children worldwide are achieving basic literacy and numeracy. ${ }^{62}$

These findings are troubling for children who are already in classrooms, but also may lead to more children missing out on education entirely. Concerns about inadequate educational quality may deter some families from sending their children to school, especially if a child's school attendance means reduced household earnings.

\section{Discrimination and Exclusion}

Finally, discrimination within classrooms against girls or students from particular racial, linguistic, or economic backgrounds, or disparities in school quality that disproportionately affect particular groups, continue to create barriers to equal chances at education. In many countries, students with disabilities still face widespread exclusion from mainstream schools due to discrimination or inaccessibility, while other students lack access to education in their native language. Meanwhile, 
discrimination in education can have profound consequences for societies' overall inclusiveness and equality. Research shows that inclusive and integrated educational settings are best suited to prepare all students to live and learn together. ${ }^{63}$ In short, proactive efforts to prevent discrimination in schools are vital to both students' ability to learn and a country's success.

Critically, to ensure the right to education is fully accessible to all, reducing discrimination and promoting integration are equally important in public and private schools. In a substantial number of countries, a significant portion of children attend private schools. ${ }^{64}$ In Australia, for example, $41 \%$ of secondary students are enrolled in private schools. ${ }^{65}$ In Uganda, $27 \%$ of primary schools and $66 \%$ of secondary schools are private. And globally, private education is on the rise: UNESCO reports that the share of secondary school students enrolled in private institutions worldwide increased from $19 \%$ in 1998 to $27 \%$ in $2017 .{ }^{66}$ These high ratios have triggered equity-related concerns among civil society groups, who suggest that these schools take advantage of inadequate investments in public education to convince lower-income families that private schooling is necessary, even as private educational offerings vary in quality. ${ }^{67}$

\section{EDUCATION FOR ALL: ENSHRINING EFFECTIVE APPROACHES IN CONSTITUTIONS}

Ensuring that education yields the maximum possible benefits requires addressing equal access to quality education from a young age. While removing barriers to higher education is also essential, investing in schooling from the very beginning is critical for providing all children with opportunities to reap education's benefits for their health, economic mobility, and future careers. It is also clear that addressing education alone is insufficient to create an equal playing field in the labor market-one reason the comprehensive protections of equal rights and nondiscrimination discussed in the first half of this book are so critical. Education can indeed be transformative, but every piece of a country's social and legal fabric works together to shape access to opportunities and resources.

While the challenges are complex, some solutions are relatively straightforward, such as reducing educational costs and requiring governments to prevent discrimination and ensure schools are universally available. These approaches also align with countries' commitments under international treaties including the CRC. The CRC recognizes every child's right to an education, requires parties to ensure primary education is free and compulsory, and urges parties to make secondary "available and accessible to every child," including by providing free education. The CRC also commits countries to respect the rights of every child "without discrimination of any kind" including on the basis of "race, colour, sex, language, religion, political or other opinion, national, ethnic or social origin, property, disability, birth or other status." Importantly, the CRC has been ratified by 196 countries and territories, including all but one country-the United States-worldwide. 
The ICESCR embodies the same commitments for education, and also articulates the standard of "progressive realization," which applies to aspects of education rights as well as other social and economic rights. This standard requires countries to invest greater resources in education as their economies grow, with the goal of expanding the availability of free education at the secondary level and beyond. Eliminating primary-level tuition and ensuring nondiscrimination are immediate obligations. In 1999, the U.N. Committee on Economic, Social and Cultural Rights provided further guidance on the right to education, specifying four elements central to its realization: adaptability, accessibility, availability, and acceptability. ${ }^{68}$ How do these commitments align with constitutional approaches, and what is their potential for impact on the key barriers identified?

\section{Adaptability: Keeping Up with Evolving Educational Standards}

Countries across all regions and income levels have adopted constitutional rights to education, which have become more prevalent over time. As of $2017,83 \%$ of countries take some constitutional approach to protecting the right to education, either protecting education as an individual right or making clear the state's obligation to provide education for all (Map 25). Less than two-thirds of constitutions adopted before 1970 include a right to education, compared to all constitutions adopted since 2000 .

Further, evidence suggests that a constitutional right to education supports enrollment rates. In a 2013 global study of constitutions, those that took some approach to guaranteeing the right to primary-level education reported primary enrollment rates that were, on average, 4.8 percentage points higher than those in countries without a constitutional guarantee. Likewise, looking at constitutional protections for the right to secondary education, the associated net secondarylevel enrollment rates were 8.3 percentage points higher than in countries without such a provision. ${ }^{69}$

Beyond whether to protect the right to education generally, a key question is what level of schooling this right should include. Globally, $60 \%$ of constitutions explicitly guarantee the right to primary education, while $33 \%$ explicitly extend this guarantee to secondary education. Just $17 \%$ guarantee the right to tertiary education (Map 26). Seventy-seven percent generally guarantee the right to education, either in addition to or without specifying levels (Map 27).

A small number of countries specify age ranges for education rights, typically in designating how long education will be compulsory or free. For example, Lithuania's constitution provides: "Education shall be compulsory for persons under the age of $16 .{ }^{\prime 7}$ Brazil's constitution establishes a specific age range for free and compulsory education but clarifies that these parameters are not intended to exclude those who missed out on schooling as children: “The National Government's duty towards education shall be effectuated through the guarantees of: I. free, compulsory elementary education from 4 (four) to 17 (seventeen) years of age, including 


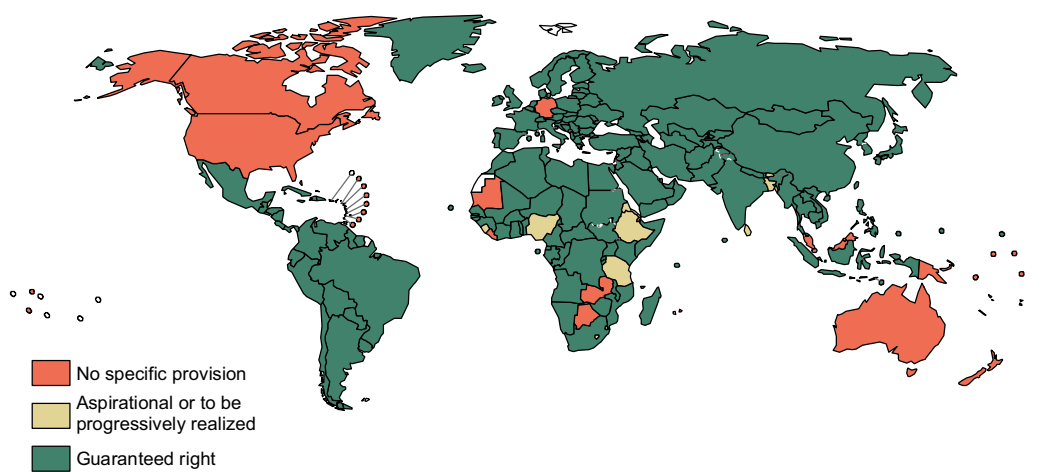

MAP 25. Does the constitution explicitly guarantee some aspect of citizens' right to education?

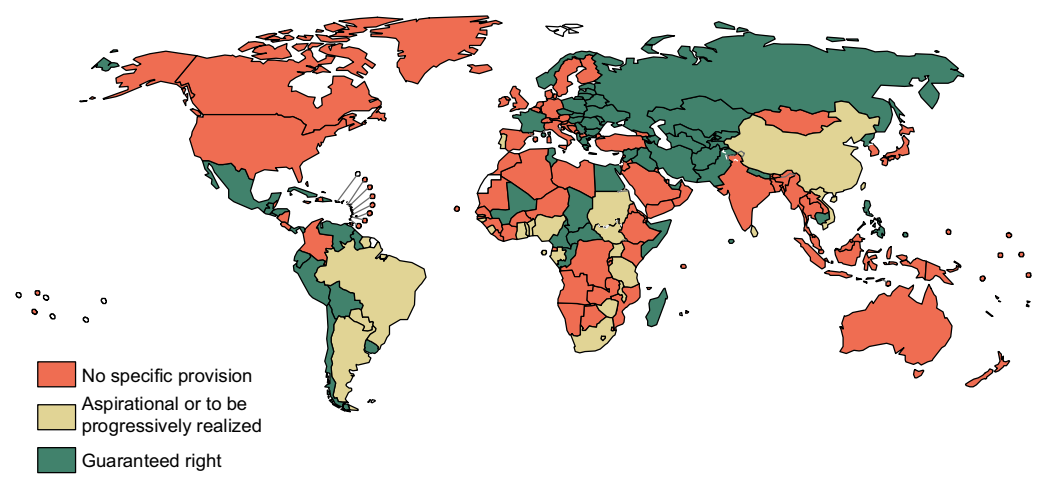

MAP 26. Does the constitution explicitly guarantee citizens' right to secondary education?

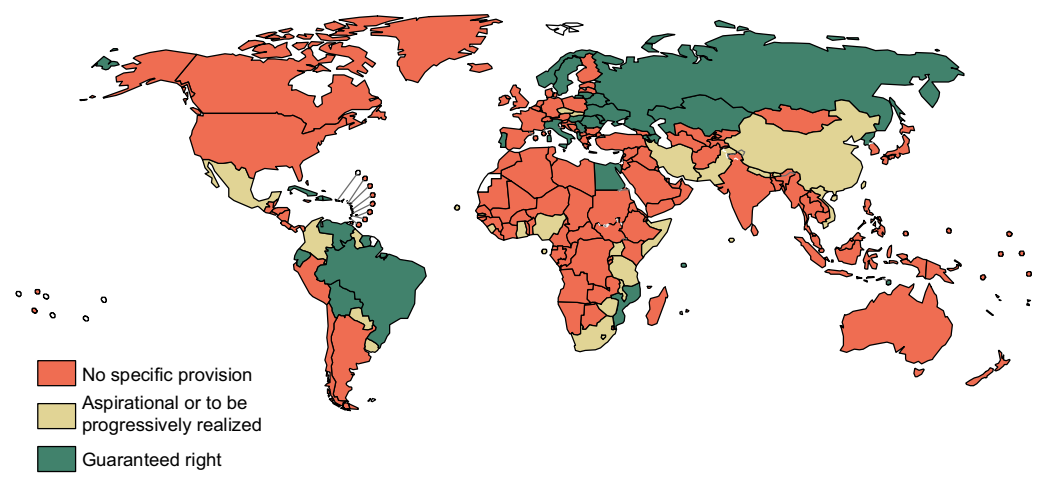

MAP 27. Does the constitution explicitly guarantee citizens' right to higher education? 
assurance that it will be offered gratuitously to all who did not have access to it at the proper age." ${ }^{71}$ Six percent of countries establish specific age ranges for which education is compulsory, and two countries do so for free education.

Whether the right addresses a designated age group or schooling level can matter for vulnerable students. In some countries, grade repetition is high. Similarly, students who started school late (whether because of conflict, inaccessibility, costs, or other barriers), as well as students with cognitive disabilities, may be placed below the typical grade for students their age. Limiting education rights to a certain age range may unnecessarily impede the completion of such students' schooling.

Additionally, $12 \%$ of constitutions include explicit provisions addressing adult education, including adult literacy or continuing education programs. For example, Costa Rica's constitution provides: "The State shall organize and support adult education, designed to combat illiteracy and to provide cultural opportunities for those who wish to improve their intellectual, social, and economic position."72

Adaptability requires that the right to education meet "the needs of changing societies and communities."73 To advance adaptability, constitutions can ensure that their protections of education rights keep pace with expanding educational standards.

In considering adaptability, it is worth returning to the primary purpose of a constitutional right to education: to ensure that all children, regardless of other circumstances, have an equal chance to obtain the education level necessary to fully participate in society and lead full lives. Exactly what this means in different contexts will change over time. For example, in most countries, a primary education no longer suffices to secure a job paying a decent wage or participate in all aspects of civil and political life-secondary and higher education have become increasingly critical for competitiveness in the labor market. Yet the economic barriers to secondary-level enrollment and attendance are greater than for primary, and competing economic pressures too often compel students to put work before school as they get older. While overcoming those pressures will require action on many fronts-including ensuring adults can earn wages sufficient to support their families so children need not labor-a constitutional right extending to secondary education can make a difference, especially if it also explicitly guarantees that secondary will be free.

Across countries, given the importance of reaching a certain level of educational attainment for future job prospects, the level of schooling a constitution protects, and whether the right's scope keeps pace with education requirements for strong employment opportunities, can have real implications for the goal of equal opportunity. While a general "right to education" may suffice to protect equal chances over time if courts and administrators interpret it through an equal opportunity lens, advantages may also lie in using specific language to ensure the right applies at the higher levels that can be most critical for shaping individuals' futures. 
Further, as evidence mounts about pre-primary education's importance for early childhood development, ${ }^{74}$ it has become clear that expanding educational guarantees to include earlier education is critical to achieving equality. Yet few constitutions address this right. The core question is how to design a constitutional right to education that provides both strong and specific enough protections and can easily adapt as educational standards rise and new evidence emerges.

In countries where amending constitutions is especially difficult, a broad guarantee of the right to education may be the most adaptable approach to ensuring the right keeps up with evolving educational standards. This can be strengthened by specifying all education levels that should be guaranteed and free at the time of enactment and noting that additional education should be covered if it becomes important to full equality of opportunity at work and in civil life.

However, it is not enough to only specify lower education levels. If the constitution explicitly guarantees the right to primary school but does not mention secondary, courts may interpret the right to education narrowly, thus limiting a constitution's potential to continue supporting equal educational opportunities as minimum standards rise and a country's ability to invest in education increases. By contrast, a broad guarantee of the right to education can provide courts and advocates with a tool to build and expand the right to education as development and educational expectations evolve. So too can specifying levels currently covered and explicitly stating criteria for additional levels of coverage in the future.

\section{Accessibility: Addressing Income Barriers and \\ Discrimination in Education}

While protecting the right to education broadly and at expanded levels is an important first step, accessibility requires that countries also actively reduce the economic and social barriers to schools, and ensure all students have an equal chance to get an education. ${ }^{75}$ Two key ways that constitutions can advance these goals are by reducing or eliminating educational costs and by prohibiting discrimination in all forms.

In many countries, making school tuition-free has markedly increased enrollment, especially by girls and other marginalized students. For example, when Ghana first piloted free primary education in 40 districts, overall enrollment increased $14.6 \%$, and gender and economic disparities decreased. ${ }^{76}$ Likewise, in Uganda, which introduced free primary throughout the country in 1997, primary school attendance rates increased from $62 \%$ in 1992 to $84 \%$ in 1999, while inequalities in enrollment across gender and income dropped. ${ }^{77}$

Because the children of mothers who receive an education are healthier, making school tuition-free can also drive important health improvements. A 2014 study of 37 LMICs found that establishing tuition-free primary education was associated with 15 fewer infant deaths per 1,00o live births by young mothers who 
were primary-school-age when it was free, adjusting for household socioeconomic status. ${ }^{78}$ As this example suggests, well-designed and implemented legal commitments to education can yield positive impacts for generations.

Enshrining the right to free education in constitutions, rather than laws and policies alone, can provide more powerful and enduring protection, as illustrated by the introductory case from Colombia. A country's constitutional guarantee of tuition-free education safeguards against regression during conflict, economic instability, or political shifts resulting in the imposition of new fees or the repeal of protective policies.

While provision of free basic education requires government investment, numerous lower-income countries have demonstrated its feasibility. ${ }^{79}$ As of 2017, 53\% of constitutions, spanning all regions and income levels, established that primary school would be free (Map 28). ${ }^{80}$ These guarantees are more common among more recently adopted constitutions. Whereas only one-third of constitutions adopted in the 1960 guarantee free primary education, two-thirds of those adopted between 2010 and 2017 do so. However, these guarantees drop off at the secondary level: just $30 \%$ of constitutions guarantee free secondary school (Map 29).

Laws and policies also reflect governments' more modest efforts to ensure free secondary education compared to free primary. ${ }^{81}$ Yet greater investment is often feasible; policymakers could improve affordability if they prioritized education. As of 2014, among countries that had yet to legally guarantee free secondary school, nearly half were spending less than $4 \%$ of their GDP on education. ${ }^{82}$ The Education Framework for Action, an agenda for expanding access to education and attainment adopted by UNESCO in 2015, recommended that countries' investments in education equal at least $4-6 \%$ of GDP. ${ }^{83}$ While national investment is always critical and may suffice in many countries given adequate political will, some of the poorest countries will likely need transitional support from the global community to make quality secondary education free. After investment generates improved educational outcomes and rising GDP, they too will be able to provide free secondary education from their own budgets.

Finally, reducing university tuition barriers can be an important way to strengthen the impact of higher education on social mobility and other economic outcomes (Map 30). While only one factor in social mobility, access to affordable, high-quality higher education is key. Many of the OECD countries that consistently rank highest for social mobility, such as Norway, Finland, and Denmark, are also among those providing free university education. ${ }^{84}$ For example, in Finland, students whose parents have a university education are only 1.4 times more likely to attend university themselves, compared to six times as likely in the United Kingdom, which charges tuition; in other words, parental education levels play a smaller role in shaping children's opportunities in Finland. ${ }^{85}$ Social mobility in the United States, which charges high university tuition, is low compared to in other high-income countries. ${ }^{86}$ Access to lower-cost higher 


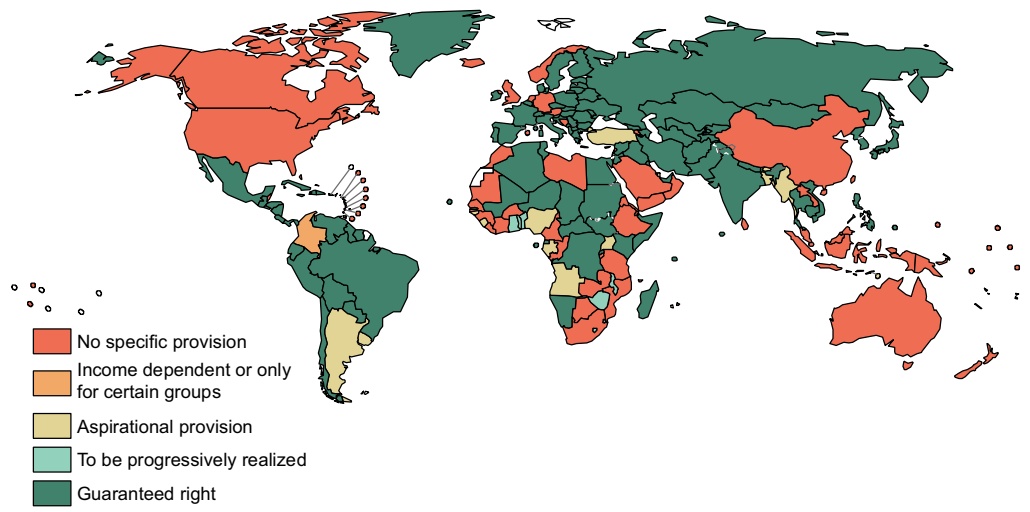

MAP 28. Does the constitution explicitly guarantee citizens' right to free primary education?

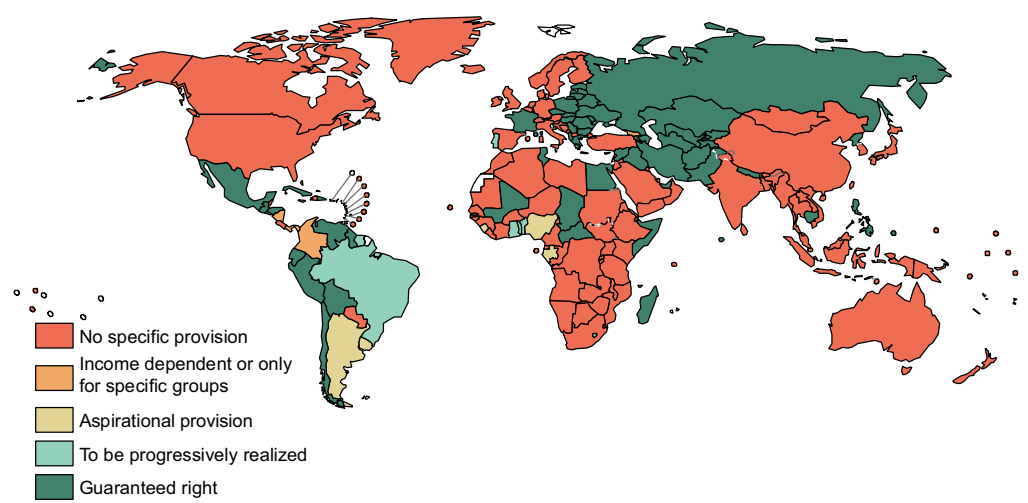

MAP 29. Does the constitution explicitly guarantee citizens' right to free secondary education?

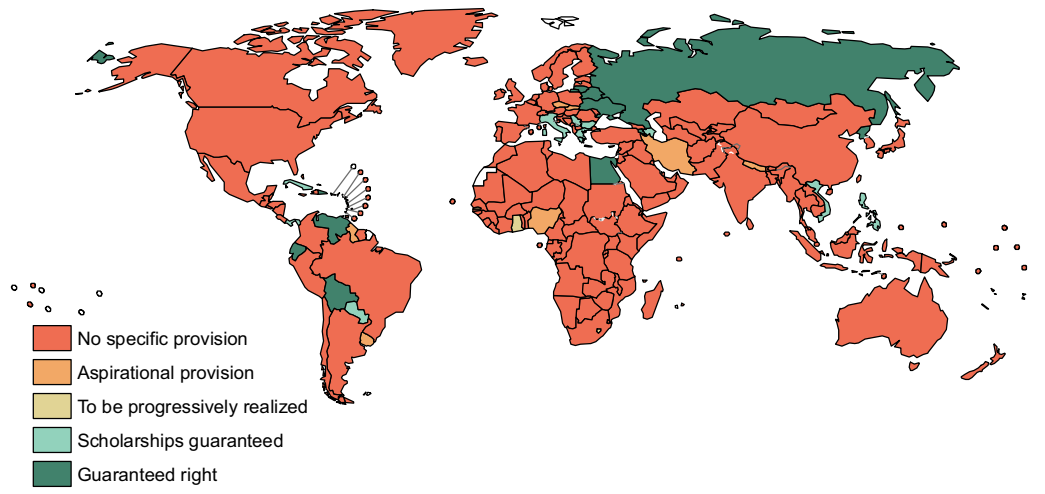

MAP 30. Does the constitution explicitly guarantee citizens' right to free higher education? 
education, where it exists, has been shown to raise social mobility. Specifically, lower-cost public universities and community colleges top the list of schools where U.S. students are most likely to ascend from the bottom income quintile to one of the top three. ${ }^{87}$

Still, reducing or eliminating tuition alone may be insufficient to eliminate socioeconomic disparities in higher education, especially when inequities persist at lower levels of schooling. Across Ecuador, Brazil, Argentina, and Mexico, case studies and comparative analyses suggest that the lowest-income students continue facing obstacles to access and completion even when tuition is removed. As in the U.S., in some countries, this results from disparities in primary- and secondarylevel educational quality that leave students from poor families less prepared. ${ }^{88}$ If these students cannot pass the rigorous entrance exams required for free public universities, their only options are expensive private schools. In Nicaragua, for example, two-thirds of enrolled college students from the lowest income quintile attend private universities, despite the availability of free public tertiary education. ${ }^{89}$

As these examples suggest, making higher education tuition-free or lowcost can significantly broaden access by students from all socioeconomic backgrounds. Six percent of constitutions guarantee the right to free tertiary education, while an additional six percent provide for scholarships to facilitate attendance. Still, while expanding the affordability of tertiary education is critical, taking this step alone will not ensure social mobility. Addressing educational disparities that surface at much younger ages-including by ensuring pre-primary, primary, and secondary education are tuition-free; reducing the social and financial barriers to pursuing post-secondary schooling; and addressing broader labor market discrimination that shapes the value of educational credentials—are all similarly important..$^{\circ}$

\section{Progressive Realization of Higher Levels of Guaranteed Free Education}

As noted earlier, countries are immediately obligated only to make education tuition-free at the primary level. Yet under the ICESCR principle of progressive realization, countries must also take steps "to the maximum of [their] available resources" to eliminate tuition barriers at higher levels. ${ }^{91}$ Enshrining commitments to secondary and tertiary schooling is an important step toward broader fulfillment of the right to education.

Some countries' constitutions specifically invoke the language of progressive realization, consistent with international agreements. For example, Ghana's constitution provides: "[S]econdary education . . . shall be made generally available and accessible to all by every appropriate means, and in particular, by the progressive introduction of free education." ${ }^{92}$

In addition to the $53 \%$ of countries that guarantee the right to free primary education, $4 \%$ of countries specify that free primary education will be 
progressively realized, and $8 \%$ aspire to providing free primary education. ${ }^{93} \mathrm{Sim}$ ilarly, in addition to the $30 \%$ of countries guaranteeing free secondary education, $5 \%$ have committed to progressively realizing the right, and five countries aspire to it. ${ }^{44}$ Finally, on top of the $6 \%$ that include guarantees, $2 \%$ of constitutions commit to the progressive realization of free higher education, while $4 \%$ include aspirational provisions.

\section{India and Swaziland: Moving from Aspirational to Firm Commitments}

In two cases where aspirational or progressive realization provisions were especially successful, countries put a time horizon on the right to free education becoming enforceable, providing a tool for advocates as that deadline approached or passed. As discussed earlier, in India, the directive principle on education specifying it would become an enforceable right within ten years provided textual fuel for the movement to pass new legislation and, ultimately, a constitutional amendment. Likewise, in Swaziland, a constitutional deadline for free education gave parents a tool for accountability.

Indeed, in 2009, a group of parents brought a case to enforce Section 29(6) of Swaziland's 2005 constitution, which provides: "Every Swazi child shall within three years of the commencement of this Constitution have the right to free education in public schools at least up to the end of primary school, beginning with the first grade." As the parents argued, free primary education was a right subject to immediate, rather than progressive, realization. In other words, the cost of basic education could not excuse the government from providing it, since free primary school was a "minimum core obligation" of fulfilling the right to education. ${ }^{95}$

However, while the High Court ruled in the parents' favor, in a follow-up to enforce the judgment, it found that although "the Government demonstrated that it had taken steps towards implementation of a program for free education . . . there was no evidence that the Government had resources available at that time to fulfil its constitutional obligation." ${ }^{96}$ In other words, the Court accepted the government's rationale that progressive realization was the appropriate standard. ${ }^{77}$ The Supreme Court upheld this decision in 2010, dismaying activists who felt it undercut Swaziland's commitments under international law. That same year, however, the legislature passed the Free Primary Education Act of 2010, which rolled out free primary grade by grade from 2010 to $2015 .^{98}$

As this example shows, when constitutions use progressive realization language to describe rights that should be immediately realizable, they risk letting courts define the government's obligation in a way that falls short of global standards. At the same time, including a "deadline" for realizing a right can provide a tool for citizens and activists. Whether a time horizon, as used in India and Swaziland, or an income or GDP horizon that kicks in when additional financial resources are available, specifying when a goal must be achieved can accelerate action. 


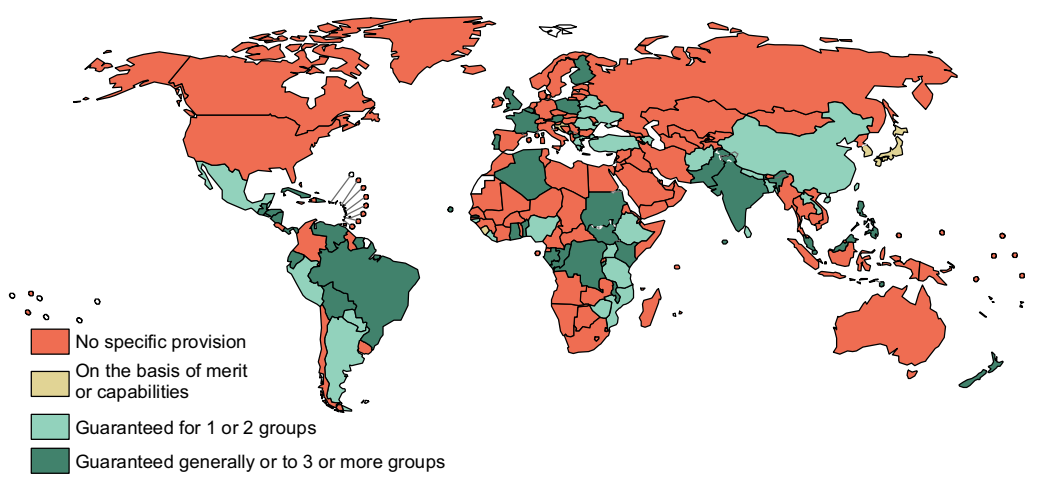

MAP 31. Does the constitution explicitly guarantee equal opportunities or nondiscrimination in education?

\section{Prohibiting Discrimination in Education}

Beyond reducing financial barriers, ensuring equal access to education also requires guaranteeing equal opportunities for all children in education and/or prohibiting discrimination in education on the basis of race/ethnicity, gender, disability, religion, sexual orientation and gender identity, and other characteristics. While substantive rights like the right to free education provide essential building blocks for opportunity, their full effectiveness relies on a critical foundation of nondiscrimination and addressing histories of past discrimination.

Only $22 \%$ of constitutions explicitly guarantee nondiscrimination or equal opportunities in education generally or to three or more groups (Map 31). An additional $13 \%$ of constitutions provide these guarantees to one or two specific marginalized groups. For example, Peru's constitution states: "It is the duty of the State to insure that no one should be prevented from receiving an adequate education on account of his economic circumstances or his mental or physical disabilities." 99

Four constitutions contain provisions guaranteeing children equal opportunities in education on the basis of merit or capabilities. Without a nondiscrimination clause, language about "merit" or "capabilities" may open the door to significant discrimination. First, explicit and implicit bias shape perceptions of "merit" and "capability" and studies have shown that children from different marginalized groups are commonly perceived as less "capable" or deserving than other students. Second, for students with disabilities or different abilities, who already face widespread exclusion from education, this language could easily serve as a mechanism for further discrimination. Moreover, under the Convention on the Rights of People with Disabilities, there is no justification for excluding any child from education based on perceived capabilities; states must provide an "inclusive education system at all levels," including the reasonable accommodations that ensure education is universally accessible. ${ }^{100}$ 


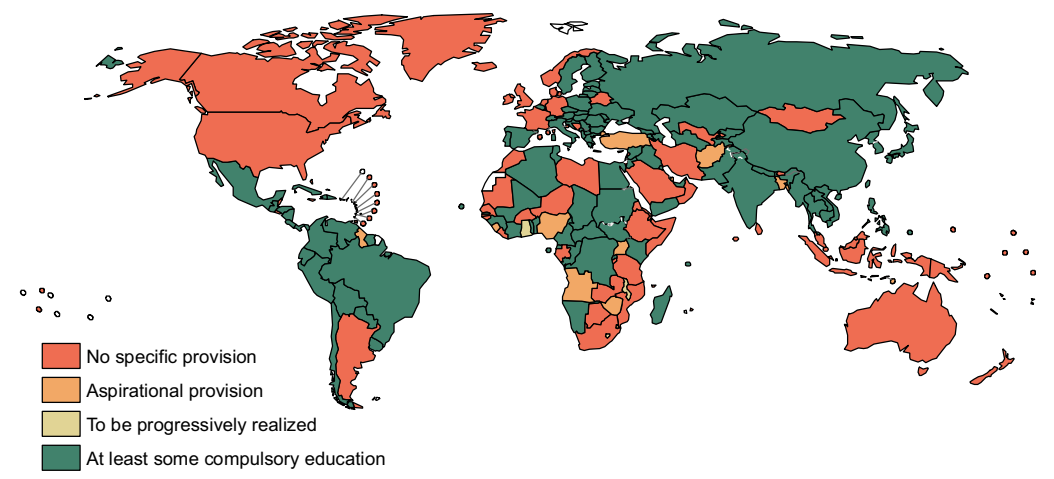

MAP 32. Does the constitution explicitly provide for compulsory education?

\section{Availability: Ensuring Governments Make Quality Public Schools Available to All}

Ensuring that education is adequately "available" means providing sufficient numbers of functional schools throughout countries. One way that constitutions can support the availability of education is establishing that school is compulsory. ${ }^{101}$

Making school mandatory implicitly commits governments to ensuring that staffed schools are available and accessible to all children, while encouraging parents to send their children to school rather than keeping them home to help with household or other work. Compulsory education can also encourage enrollment and support students to stay in school longer, rather than dropping out to work full-time. For example, after the U.K. extended mandatory education from age 14 to age 15 in 1945, 14-year-olds' dropout rate fell from $57 \%$ to below $10 \%{ }^{102}$ In a study across 12 European countries that enacted reforms lengthening compulsory education between 1949 and 1983, researchers found increases in both educational attainment and wages. ${ }^{103}$ In China, average years of education increased from fewer than five to over eight from the early 1980s to 2004, corresponding with the introduction of nine years of compulsory education in $1986 .{ }^{104}$ However, if school is to be compulsory, it is especially important that it also be free, so as not to saddle the poorest families with mandatory tuition and fees or make them targets for prosecution.

As of $2017,52 \%$ of constitutions explicitly make at least some education compulsory, and an additional $8 \%$ either aspire to compulsory education ${ }^{105}$ or commit to progressive realization of compulsory education (Map 32). Eighty-nine of these 117 constitutions make specific levels of education compulsory, as opposed to specifying the ages at which children must be in school. Two countries (Colombia and Pakistan) address both the level and ages at which education is compulsory. Colombia's constitution states: "The State, society, and the family are responsible for education, which will be mandatory between the ages of five (5) and fifteen (15) 
years and which will minimally include one (1) year of preschool instruction and nine years of basic instruction." ${ }^{106}$ Seventeen constitutions with compulsory education provisions do not specify the duration of compulsory schooling or the ages at which school attendance is mandatory.

\section{Acceptability: Improving Education Quality}

Quality of education shapes learning-invaluable for its own sake-and all the outcomes associated with learning, literacy, and numeracy, from health to employment and income. Specific guarantees of factors that affect quality rarely appear in constitutions. Quality can be transformed by teachers and pedagogical approaches and affected by factors including teacher training, student-teacher ratios, the availability of supplies, curriculum strength, and school infrastructure, including transportation and sanitation.

While constitutions are not the location to embody specific approaches to education - an area where best practices may rapidly evolve-constitutional rights to education can provide a basis for advocacy to address quality. For example, several U.S. state constitutions guarantee a right to education and either reference quality or include specific provisions. Florida's constitution, for instance, provides: "The education of children is a fundamental value of the people of the State of Florida. It is, therefore, a paramount duty of the state to make adequate provision for the education of all children residing within its borders. Adequate provision shall be made by law for a uniform, efficient, safe, secure, and high quality system of free public schools that allows students to obtain a high quality education and for the establishment, maintenance, and operation of institutions of higher learning and other public education programs that the needs of the people may require."107

In states like Arkansas and Montana, advocacy groups successfully challenged school financing policies based on their state constitutions' specific commitments to "quality" education. ${ }^{108}$

Similarly, in South Africa, advocates invoked the constitutional right to education in two cases to compel the government to supply desks and chairs for classrooms ${ }^{109}$ and updated textbooks corresponding with a new curriculum. ${ }^{110}$ The latter case also relied on the constitution's equal rights guarantee, and interpreted the disparities in quality of materials - which disproportionately affected black students - as discrimination. With a broad guarantee of education rights and quality, and clear language prohibiting discrimination, parents and civil society may have the greatest flexibility to leverage constitutions to achieve these types of improvements, as evidence on which interventions are most effective continues to develop.

\section{Private Schools: The Last Refuge and the State Escape}

Finally, two aspects of private education should concern any government. The first is ensuring that it is not necessary. For the true fulfillment of children's right to 
education, free, accessible, and available public education must be of sufficient quality that families are not forced to send their children to private school for a good education. Absent this, the right to education is only nominal. In settings where elementary school students find themselves in a classroom of 300-400 other students and a teacher inevitably unable to teach, the education is only nominal. Likewise, in a school setting with neither desks nor books, no right to education is fulfilled.

The second way in which private education must concern governments is the prohibition of discrimination. Discrimination in private schools not only erodes equal access and equal opportunity for students who would but cannot attend, but also trains youth who may be headed for public- or private-sector leadership positions that people are created unequal and segregation is natural.

Importantly, a few constitutions explicitly establish that their protections of equal access to education apply to both public and private schools. For example, Panama's constitution provides: "Educational institutions, whether public or private, are open to all students without distinction of race, social position, political ideology, religion, or the nature of the relationship of the student's parents or guardians." ${ }^{111}$ Likewise, Ecuador's constitutional provision on higher education establishes: "Regardless of their public or private character, equality of opportunities with respect to access, permanence, passing and graduation shall be guaranteed, except for the charging of tuition in private education." ${ }_{112}$ While courts have also provided important rulings extending protection from discrimination to private institutions, in the context of growing privatization of education, constitutional language which makes it clear that antidiscrimination provisions apply to private schools is likely to become increasingly important.

\section{WHEN CONSTITUTIONS ARE SILENT ON EDUCATION}

As in other areas, when constitutions' protections for education are not explicit, the extent of their coverage is unpredictable. Two contrasting cases on the right to education, from Israel and the United States, illustrate how constitutional silence can yield strongly contrasting outcomes, with diverging implications for equality.

\section{Israel: Geographic Accessibility of Schools}

In Israel, the High Court of Justice addressed schools' geographic accessibility in an important 2011 ruling. Since 2001, Palestinian families had been filing complaints about the inadequate number of free public schools in their neighborhoods, which had compelled many families to send their children to expensive private schools or "unofficial" schools instead. ${ }^{113}$ All told, just over half the children in East Jerusalem who were legally entitled to attend free public schools were in fact attending. ${ }^{114}$ The petition before the Court was brought by five students, ranging from second to ninth graders, who had attempted to enroll at nearby public schools but were rejected because of classroom shortages. ${ }^{115}$ 
In its decision, the Court acknowledged that the constitutional text did not specifically address the right to education. However, education is fundamental to other enumerated rights, justifying its protection. As the Court explained: “The right to education is entwined as a basic element in the entire moral infrastructure of the constitutional system of Israel. ... The realization of additional basic rights is premised on the right to education, such as the freedom of speech and the ability to obtain information, the freedom to elect and be elected, the freedom of association and freedom of occupation. In the absence of the right to education, such other rights may also be infringed." ${ }^{116}$

The Court further found that the right to education was a core component of the right to dignity and went "hand in hand with the right to equality, jointly forming a right to equality in education." ${ }^{117}$ As a remedy, the Court ordered the government to "create a gradual physical infrastructure which will enable the integration of all East Jerusalem students who are entitled to free compulsory education and who wish to receive same, into the official education framework in the city" within five years. ${ }^{118}$ If it failed to comply, it would be required to pay private-school tuition for the students who could not be accommodated in the public system. By 2015, while the decision had not been fully implemented, 195 new classrooms had been built. ${ }^{19}$

\section{United States: Unequal Funding}

By contrast, in a notorious 1972 case, the U.S. Supreme Court reached a different conclusion about the constitution's silence on education rights. The case originated at Edgewood High School in San Antonio, Texas, where 400 students walked out of class on May 16, 1968, protesting insufficient supplies and poorly trained teachers. ${ }^{120}$ The students' action prompted their parents to organize and join their calls for change through the newly formed Edgewood District Concerned Parents Association, led by Demetrio Rodríguez, a sheet metal worker.

The group quickly uncovered the critical funding disparities underlying their children's grievances. In Edgewood, which was at the time 90\% Mexican American, educational spending per pupil was only $\$ 356$; in Alamo Heights, another San Antonio district that was $80 \%$ white, spending was $\$ 594$ per pupil. ${ }^{121}$ The gap stemmed from Texas's policies around education financing, which funded public schools partly through local property taxes. Consequently, students in less wealthy districts-who were disproportionately from Mexican American families-had access to lower-quality schools than their more well-off counterparts.

Later that year, Rodríguez and his fellow parents went to court, challenging the education finance policy as discriminatory against low-income families, and an infringement of the fundamental right to education. In 1973, however, the Supreme Court overturned a favorable district court ruling in a 5-4 decision, finding that the constitution does not explicitly establish education as a fundamental right and thus does not compel a "strict scrutiny" review of the policy. Further, building on prior cases, the Court reiterated that discrimination on the basis of wealth does 
not require a heightened standard of review, unlike discrimination on the basis of race or gender. In his dissent, Justice Thurgood Marshall, a champion of civil rights, called the decision "a retreat from our historic commitment to equality of educational opportunity." 122

Justice Marshall's critique proved prescient. While the 1954 Brown v. Board of Education ruling formally desegregated U.S. public schools, the Supreme Court's decision in San Antonio v. Rodriguez eroded protections and contributed to the de facto resegregation, massive disparities in public school quality, and unequal educational opportunities found across the U.S. today. More recently, lawyers brought a class action lawsuit against the State of Michigan on behalf of Detroit public school students, alleging that the failure to provide trained teachers, textbooks, and safe learning conditions violated students' "fundamental right to literacy," which they argued was inherent to their constitutional right to liberty. While a lower court ruled in July 2018 that no such right exists, in November 2018, the Detroit students appealed, supported by an amicus brief filed by nearly 70 educators and organizations (and counting). ${ }^{123}$ In other words, the fight for education rights continues. However, for now, the ruling in San Antonio v. Rodriguez poses a barrier to equal opportunities to education, and powerfully illustrates what is at stake when such foundational rights remain unwritten.

With no national guarantees of educational equality, many states have enshrined the right to education within their own constitutions, which in some jurisdictions have provided tools for reforming school finance and challenging inequity. ${ }^{124}$

\section{Why Enshrining the Right to Education in the Constitution Makes a Difference}

As these examples underscore, while regular legislation and detailed education policies are critical elements of a strong education system, constitutional rights matter to equality and accountability. And although court decisions can advance rights in common law countries, enshrining the right to education in the constitutional text more powerfully and permanently assigns the state responsibility for ensuring schools are widely available and adequately staffed, and provides citizens with a straightforward tool to hold their governments accountable. Moreover, in common law countries like the U.S., once the constitutional court has determined there is not a right to education, the challenge of overturning precedent becomes a significant barrier, even as constitutional education rights become more common globally.

\section{BUILDING ON PROGRESS AND ADDRESSING PERSISTING GAPS}

In recent decades, national and global efforts have been remarkably successful at expanding access to primary and secondary education and reducing gender disparities. Since 2000, the number of out-of-school children globally 
has dropped by nearly half, while gender gaps at all levels of education have substantially narrowed. ${ }^{125}$

Still, much work remains to truly achieve education for all. Fifty-seven million children of primary school age remain out of school globally; 55 percent are girls. ${ }^{126}$ In nearly one-third of developing countries, girls remain at a disadvantage in accessing both primary and secondary school, perpetuating gender gaps in wages and employment. Although secondary enrollment rates have markedly improved, completion rates have not risen quite in step, while across education levels, upholding quality remains a key challenge. Finally, children with disabilities remain particularly at risk of exclusion: in a study covering 13 LMICs, the gap in school attendance between 6- to 11-year-olds with disabilities and children in the same age group without disabilities ranged from 10 percentage points in India to nearly 60 percentage points in Indonesia, with even greater disparities among older children. ${ }^{127}$

Taking the next step toward education for all will require addressing gaps in laws and implementation, accelerating progress on norms, and ensuring that policies and programs comprehensively support all children's ability to learn and think critically.

\section{Further Constitutional Rights Needed to Make the Right to Education Meaningful}

Fulfilling the right to education requires teaching students how to learn, question, and find solutions-not indoctrinating them. Historically, schools have been used for both. Autocratic regimes have taught their own versions of history. Democracies, too, have often neglected to ensure that education includes the experiences, perspectives, and history of minority populations and those out of power as well as majority populations and those in leadership positions. Yet if education is to enable the exercise of full civil and political rights, and give citizens the chance to learn from history, then we must ensure opportunities for students to wrestle with difficult questions, to hear a multiplicity of viewpoints, to sort through the evidence, to learn how to learn and how to think.

Three other rights make a difference in this process: the right to information, the right to free speech, and freedom of belief. Globally, nearly all constitutions guarantee freedom of expression (96\%), which includes the right to free speech, while $74 \%$ protect freedom of belief. Meanwhile, a growing global movement has elevated the right to information as a centerpiece of improving government accountability. Continuing to advance these rights and principles will be paramount to ensuring the right to education can be fully realized.

\section{Accelerating Change}

Important progress in constitutions over the past few decades can provide a foundation for further action (see Figure 13 ). While only $44 \%$ of constitutions adopted before 1970 ensured that primary school was free, $67 \%$ of those adopted since 


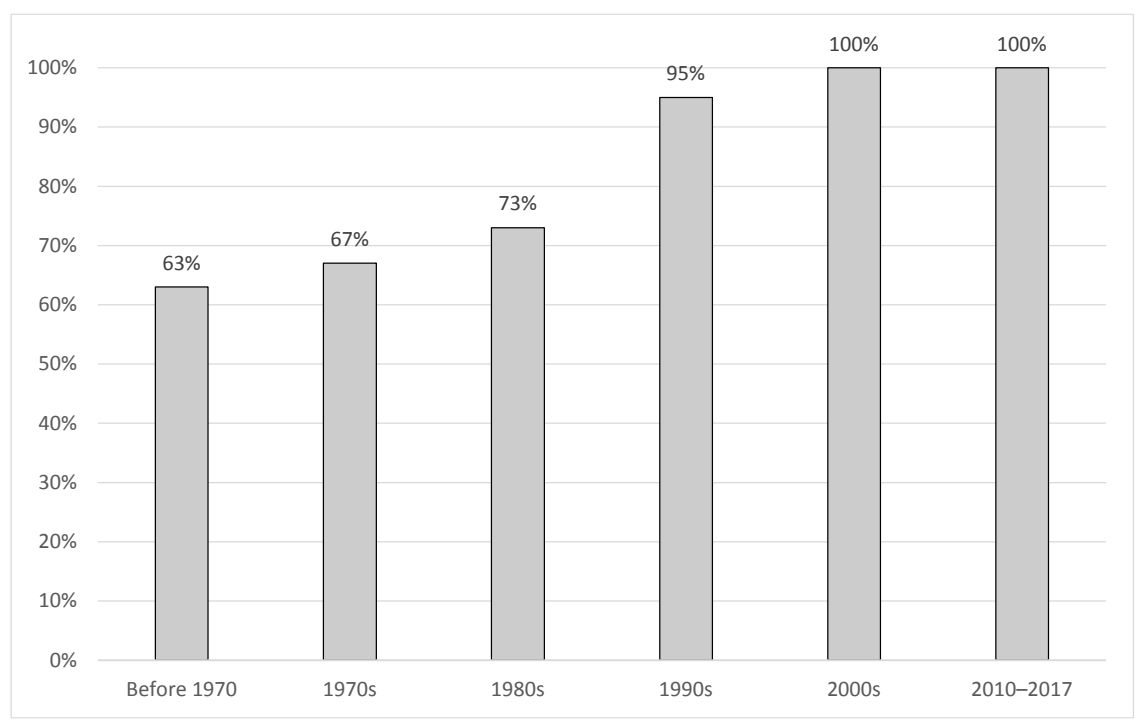

FIGURE 13. Explicit constitutional approach to protecting the right to education by year of constitutional adoption

2010 do so. At the secondary level, only $20 \%$ of constitutions adopted before 1970 addressed the right to secondary education through guarantees or aspirational language, compared to approximately $67 \%$ of those adopted since 2010. Already, constitutional guarantees have provided important bases for new legislation and judicial decisions that have resulted in increased enrollment, improved accessibility, and better resources for schools. Further, while guarantees are likelier to appear in new constitutions, it is possible to adopt or strengthen right-to-education provisions by amendment. For example, Mexico's 1917 constitution was among the first to guarantee a broad range of social and economic rights, and ensured that basic education would be free and compulsory well before many others. In February 2012, to prepare students to succeed in the twenty-first-century economy, the government extended this guarantee to secondary school. ${ }^{128}$

While the world has achieved remarkable educational gains over the past several decades, the remaining gaps should trouble us all. For society to flourish, all individuals need the opportunity to reach their potential. Today, millions of children are missing out on that chance, often simply because they were born poor, female, or with a disability. By establishing a constitutional right to education, national governments can both symbolically and practically support efforts to ensure all receive a quality education. When people have a legal right to education and the ability to pursue it, case law from around the world demonstrates its power as a tool for tearing down barriers to equal opportunity, increasing the resources devoted to schools, and giving all children a chance to thrive. 